\title{
Oil, Democracy and Internal Conflict in Sub-Saharan Africa
}

\author{
A. Kole \\ Mai Idris Alooma Polytechnic \\ Geidam str. 49, Yobe state, Nigeria
}

\begin{abstract}
This study examines the effect of oil and democracy on internal conflict in Sub-Saharan Africa (SSA). The study employed panel regression on 14 oil rich SSA spanning from 1983-2012. The major finding reveals a U-turn from the resource curse theory because it clearly shows that, increase in oil leads to a reduction in the likelihood of internal conflict situations in SSA. The study found strong evidence on the significance of political institutions in mitigating internal conflict in SSA. However, the interaction between oil and democracy reduces the risk of internal conflict in SSA countries with the lowest and average polity scores and increase conflict in those SSA with a maximum polity score. This outcome is usually expected in the course of transition from autocracy to democracy in developing countries. Therefore, with further improvement in the political institutions, the mitigating effects of oil on internal conflict will re-emerge. Impliedly, oil in itself is a blessing and leads to the realization of peace when countries improve their political institutions. Also, the study uncovered that, while real GDP reduces the chances of internal conflicts in SSA, an increase in military expenditures tends to dampen the likelihood of peace which is a bit departure from the rentier peace theory. Therefore, the study suggests that, for peace to be maintained, SSA should reduce its expenditure on the military and increase that of social spending while improving its political system.
\end{abstract}

Keywords: oil, democracy; internal conflict, panel regression, Sub-Saharan Africa

\section{Introduction}

Today, most developing economies have been heavily dependent on natural resources for growth and development. In those economies, resources such as oil play a key role in generating substantial revenue for the governments. This is in line with the assertion of the staple theory that, poor but resource-abundant economies have the potential to utilize oil income to overcome the challenges of lower capital base and to provide public goods to uplift the general wellbeing of their

(C) Kole A., 2019.

(c) (i) This work is licensed under a Creative Commons Attribution 4.0 International License https://creativecommons.org/licenses/by/4.0/ 
citizenries [1]. Interestingly, the countries of Norway, Canada and Russia have used oil income in the provision of infrastructures, and social security that improves the general wellbeing of their people. In the same vein, they expended oil income by diversifying in non-oil outlets leading to the growth and development of their economies. However, in most developing countries rich in oil, the resources breed incessant corruption and conflict. This is evident in Nigeria, Angola, and South Sudan.

This study will particularly focus on Sub-Saharan Africa (SSA) (Table 1).

Table 1

Table 1. List of Sub-Saharan African Countries employed in the Study

\begin{tabular}{|l|l|}
\hline S/N & COUNTRY'S NAME \\
\hline 1 & ANGOLA \\
\hline 2 & CAMEROON \\
\hline 3 & COTE D'IVOIRE \\
\hline 4 & CONGO \\
\hline 5 & DR CONGO \\
\hline 6 & GABON \\
\hline 7 & GHANA \\
\hline 8 & MOZAMBIQUE \\
\hline 9 & NIGER \\
\hline 10 & NIGERIA \\
\hline 11 & SENEGAL \\
\hline 12 & SOUTH AFRICA \\
\hline 13 & SUDAN \\
\hline 14 & TANZANIA \\
\hline
\end{tabular}

These countries share some common characteristics. For instance, SubSaharan Africa has the largest number of post-colonial conflict as noted by Fearon and Latin [2]. Human Security Report Project [3] opines that one-third of the world conflict-related death are found in Sub-Saharan Africa. Also, Albuja et al. [4] found that SSA has the highest number of internally displaced persons (IDP) by the end of 2012. Nonetheless, the majority of SSA countries gained independence around the 1960s. After independence, most of these countries strive to build their economic and social institutions and policies to achieve economic growth and development. As a result, SSA had experienced rapid growth in the 1960s and 1970s. During that time, SSA economies are characterized by state-owned enterprises in the provision of social services with stringent control on the financial sector. However, oil price shock in the 1970s and the debt crisis of the 1980s explicitly exposed the economic and political weaknesses of these countries. During these periods, SSA economies experienced a deteriorating economic performance, huge debt profile, and term of trade worsening. These scenarios necessitated most SSA countries to embark on structural economic adjustment in the 1980s through a devaluation of the nation currency, abolition or reduction of subsidies and reduction in a budget deficit. 
However, these policies did not yield an expected result due to weak political and economic environment coupled with internal and external conflicts. Therefore, there are several empirical studies focused on SSA countries due to the distinctive role played by the region. Interestingly, SSA countries have the largest oil reserves and production on the continent. Sadly, the region is bedeviled by internal conflict, sluggish economic growth, widespread poverty, and weak public and private institutions [5]. It is pertinent to assert that most SSA countries that are suffering from internal conflict and civil unrest have been endowed with abundant natural (oil) resources and some of these countries run a democratic regime. For example, Nigeria has returned to uninterrupted democratic regimes since 1999 and between 1970 and 2000 only, Nigeria earned about 300billion US dollars from oil export. However, despite huge income realized from oil export, about $70 \%$ of the Niger Delta population live below the poverty line ${ }^{1}[6]$. This preposition is reiterated by the World Bank [7] report that $82 \%$ of the Niger Delta population lives below 2 U.S dollars per day in 2010. This position is indifferent across most of the regions in Nigeria.

Therefore, Nigeria like other Sub-Saharan Africa countries share some common characteristics concerning the democratic system, the political economy of the resource rent, ethnic division, widespread corruption, and internal conflict. It is against this background that this study explores the effect of oil and democracy on internal conflict in Sub-Saharan Africa with important potential policy implications for sustained economic growth and development. Rest of the paper anchored on theoretical framework and empirical literature, methodology, results and discussion, conclusion and policy recommendations.

\section{Theoretical Framework and Empirical literature}

From the theoretical perspectives, there is still no clear cut mechanism through which resource rent, institution (be it political or economic) and conflicts puzzle can be addressed. This is because, the literature focuses on several theoretical propositions such as resource curse effect, institutional effect, and rentier peace effect. The resource curse theorists pioneered by Auty [8] premised on the belief that natural resources dampened the performance of the manufacturing sector and increased importation of manufactured goods in what he described as the Dutch Disease Syndrome. This view is popularized by Sachs and Warner [9]. The resource curse hypothesis may be induced by either greed [10], grievance [11] or volatility [12]. In the context of institutional effect, several factors (weak bureaucracy, state detachment, economic fragility) were reported to have induced conflicts in the literature. For instance, $[2 ; 13]$ viewed weak bureaucracy as a major factor, a situation when there is loose administrative coordination and control to counter any rebellion intent within a territory. The proponent of the state detachment hypothesis $[14 ; 15]$ argued that people might induced conflict against the

\footnotetext{
${ }^{1}$ Niger Delta region produce all the crude oil and natural gas in Nigeria.
} 
state when the government disconnects itself from the people it governs by not providing social and economic opportunities.

The economic fragility theorists believed that resource-rich countries usually have worse economic performance because of the pervasive corruption and rent-seeking behavior in the system which may spark violence conflict $[2 ; 16]$. On the same notes, Humphreys [14] reports that the absence of employment opportunities from the regular economy may lure people, especially youth to accept the price of the rebels. However, the proponent of the rentier hypothesis $[17 ; 11]$ viewed natural resources from a contrary perspective. To them, resource rent can be utilized to mitigate the onset of conflicts. This can be achieved by spending on patronage, using military might to repress any rebellion intent, offering low tax system, inhibiting social changes brought by modernization, bribery, and corruption [18] or seeking foreign support to maintain an autocratic regime in exchange of uninterrupted supply of resources [19].

From the empirical perspective, a lot of literature had studied the links between resource rent Institutions and conflicts. However, it is still unclear and inconclusive in the literature the actual path that generates conflict in developing countries- is it the natural resources endowment or absence of good institutions? On the resources led conflict perspective, the groundbreaking paper by Sachs and Warner [9] provided an empirical content to the resource curse theory pioneered by Auty [8]. Consequently, a significant number of studies examined the links between resources and conflict $[20 ; 14 ; 21 ; 22 ; 23]$. However, most of the empirics on the resource curse syndrome focused on developing countries. For instance, Le billion [24] reviewed oil and armed conflict in Africa and found that generally oil can motivate and generate the onset of conflict in Africa. Also, Wizarat [25] employed panel data from a sample of developed and less developed countries using Generalized Method of Moment (GMM) estimators spanning from 1980-2006 and found that oil, gas and coal production does not breed conflict in developed countries. However, in less developed countries, the production of oil, gas, and coal has significantly triggered world conflict. Partly these conflicts are exacerbated by the greed intent of developed countries to acquire these resources and on the other hand due to their increased supply of weapons to conflict striking countries.

Singh, et al. [11] explored oil and civil conflict and analysed the effect of public spending in mitigating violent conflicts in 148 countries spanning from 1960-2009. A non-trivial finding in the study shows that excessive military spending in countries less endowed with oil may instead fuel the conflicts. This evidence is against the repression effect theory. On the impact of mining on the conflict in Africa, Berman, Couttenier, Rohner, and Thoenig [26] used novel data from 1997 to 2010 and found that an upward swing in mineral prices have significantly contributed to violent conflict in Africa. Additionally, mineral resourcesrich countries of Africa have the likelihood of both violent conflict and increased secessionism by the insurgency group. By using logit, probit and pooled regression on annual data from 1950 to 2008, Anyanwu [27] found that African countries that are endowed with oil but ethnically and linguistically fractionalized are more likely to experience civil conflict. Elbadawi and Sato [28] investigated resource rents, institutions and violent civil conflicts employing panel data covering 
over 100 developing countries and 3600 annual observations during the period 1970 to 2010. Their findings revealed that developing countries with huge dependent on resources are more risky to armed conflict.

Meanwhile, the proponents of the rentier effect theory examined resources and conflict in a rather contrary dimension. For instance, Basedau and Lay [29] after investigated the obvious puzzle between resource curse and rentier effect, found that high oil wealth per capita mitigates the onset of violent conflictthrough large scale distribution, sizable spending on securities and intervention from foreign allied forces, thus supporting the rentier effect perspective. In the same vein, Cotet and Tsui, [17] employed data from over 100 countries on a panel regression and found that countries rich in oil but do not practice democracy spend hugely on security and defense thereby help to mitigate the onset of violence. Non-trivial findings by Singh, et al. [11] revealed that the degree of conflicts in oil-rich countries can be mitigated through military spending and that spending on welfare has a significant effect in reducing conflicts irrespective of the magnitude of oil wealth. Similarly, Taydes and Peksen [30] found that higher welfare spending in oil-rich countries lower the risk of civil conflict. By using data on Sub-Saharan Africa (SSA) spanning from 1985 to 2007, Arezki and Gylfason [31] found that SSA countries with resource rents are less likely to experience internal conflict. From a similar perspective, using Two-Stage Least Square (2SLS) on a sample of 115 countries, Bruckner and Gradstein, [32] found that, countries with large income growth induced by international oil price experienced lower political risk (conflict inclusive). By testing the rentier state argument on a sample of 148 countries using logit models from 1960-2009 Bodea, found that excessive military spending in countries rich in oil and gas resources mitigate the risk of both minor and major conflict onset. However, huge military spending in countries with lower oil and gas resources will increase the risk of civil conflict onset.

Other strands of literature link conflict in resource abundance countries to the absence of political institutions. To the supporters of this thought, resource rent inhibits democratic governance hence leading to government ineffectiveness and conflicts. For example, Fearon and Latin [2] found that neither ethnic nor religious characteristics breeds insurgency and civil war but weak bureaucracy induced by political instability and that is why Sub-Saharan Africa has the highest number of post-colonial civil war than other regions of the world. Ahmadov, Mammadov, and Aslanli [33] studied the resource-rich Caspian Basin Countries of Azerbaijan, Kazakhstan, Russia, and Turkmenistan, and found a negative impact of total natural resources rent on government effectiveness. This is because countries with higher average oil income and total natural resources income experienced lower rates of government effectiveness. A piece of non-trivial evidence by Anyanwu and Erhijakpor [34] by using both panel regression and IV-2SLS on 49 African countries found that oil wealth is linked negatively to democratization.

While these pieces of evidence focus mostly on developing countries, the story is dissimilar in Latin America. This is because Dunning [35] found that oil wealth does not hinder democracy in Latin America. His finding revealed that Latin American countries rich in oil democratized more quickly than their non-oil wealth counterparts. Also, Ross [19] using data that covers all countries from 
1960 to 2002, found that oil wealth does not inhibit democratization and resource curse syndrome in Latin America. These findings may be attributed to the existence of good institutions in Latin American countries as the findings by Ebeke, Omgba, and Laajaji [36] revealed that countries with good institutions (good governance), oil rents re-orient the redistribution of talent from grabbers (law, management, and social sciences) to producers (engineering, manufacturing, and construction). This implies that good institutions positively affect oil rents and vice versa. On the contrary, other studies do not attribute resource abundance to the emergence of conflict occasioned by weak institutions. For example, Brunnschweiler and Bulte, [37] findings revealed that resource wealth is a blessing rather than a curse for both institutional and economic development. Specifically, the result of the links between resource abundance and institutions shows a positive and significant outcome. This implies that countries with natural resources wealth will have better and strong institutions and economic growth.

Other studies attributed conflicts to the interactive effects of resource rents and the absence of institutions. For instance, Alao and Olanisakin [38] found that societies with abundant resources are prone to armed conflict especially when such resources are not properly utilized (under a political regime) to meet the needs of various groups leading to unfair and unjust resources distribution. Collier and Rohner [39] revealed that democracy with an income level below a threshold increases the incidence of conflict in developing countries. Kevin [40] findings show that countries with weak institutions (weak state capacity), the oil significantly spurs violent conflict. In a similar instance, Ross [41] findings revealed that petroleum resources are linked to a more durable authoritarian regime with a pervasive effect on government corruption and incidence of conflict onset or exacerbation of conflict, especially in low and middle-income countries. Some studies protested these findings on the ground that, the interaction between resources rent and political institution (irrespective of the degree of the democratic regime) do not breed conflict but instead reduce it. For example, in their study, Collier and Rohner, (2008) found that the interaction between democracy and high-income level (resource rent) above a threshold reduces conflict situation. Kevin [40] findings show that strong state capacity deters the tendency to have civil conflict in oil-producing countries. This implied that institutions play a mediating role in the occurrence of conflict. Arezki and Gylfason [31] found that SSA countries with huge resource rents and lower democratic scores are likely to have a lower level of conflict. This is because the possibility of large government spending from huge resource rents occurred in countries with lower democracy. Elbadawi and Sato [28] found that good economic and political institutions have a mitigating effect on the onset of civil conflict. Likewise, huge resource rents are found to have repressive and co-optation effects on the emergence of civil conflicts.

\section{Methodology}

This study employed a panel regression technique on the data on petroleum rents (oil and gas rents), democracy (Imputed polity II), internal conflict and other control variables. Specifically, the dependent variable is modeled following Arezki 
and Gylfason [31] by employing annual data on 14 Sub-Saharan African countries rich in oil from 1983 to 2012. The model is estimated using three years of data on the panel regression model within the context of Pooled, Random-Effect and FixedEffect models. Another test conducted is descriptive statistics. Data for the study is obtained from the World Bank Development Indicator (2016), ICRG (PRS, 2012), and Quality of Government (QOG) Basic Dataset, 2016.

To run the econometric exercise, the model of this study is in the spirit of Arezki and Gylfason [31] specified as follows:

$$
\begin{aligned}
\text { ICONFLICT }_{i t}= & a_{O}+\alpha_{1} \text { OIL }_{i t}+\alpha_{2} \text { POLITY }_{i t}+a_{3} \text { OIL } * \text { POLITY }_{i t}+ \\
& a_{4} Z_{i t}+U_{i t}+\phi_{i t}+\varepsilon_{i t} 3.4 .2
\end{aligned}
$$

Where $\mathrm{i}$ index-countries and $\mathrm{t}$ index-time. $a_{O}$ is constant. The dependent variable ICONFLICT stand for internal conflict. OIL, POLITY, and OIL*POLITY represent oil and gas rents as a percentage of GDP, imputed polity II, and interaction between oil and gas rents and imputed polity II respectively. The interaction of oil and gas revenues makes up a large sum of petroleum resource rent. The choice of oil and gas as against other natural resources, since they have the highest risk of civil conflict. This is because it is highly volatile and has the largest contribution to rent [1]. Democracy is measured by imputed polity II obtained from QOG datasets [42]. Imputed polity II is chosen as a democratic score because it performs better in terms of validity and reliability than polity II. $\mathrm{Z}$ stand for control variables used and $\varepsilon$ is the disturbance term. Note also, failure to capture for unobserved country-specific and country-invariant factors such as culture, climate, and geography may render our panel regression estimate biased and inconsistent. Therefore, this study includes $U_{i t}$ and $\phi_{i t}$ to capture for the country-specific and time-invariant characteristics that are common to all countries in the sample.

\section{Results and Discussion}

\section{Descriptive Statistics}

The result of the descriptive statistics is provided in table 2. It shows that internal conflict has a mean and a standard deviation of 7.26 and 2.38 respectively and it varies between a minimum of 1.36 and a maximum of 10.93. Oil has an average of 13.45 and a standard deviation of 18.91 and varies between the minimum of 0.000 and a maximum of 66.23. Polity has an average of 3.82 and a standard deviation of 2.43 and varies between the minimum of 0.75 and a maximum of 9.33. Interaction between oil and polity has a mean and a standard deviation of 41.36 and 66.06 respectively and it varies between a minimum of 0.00 and a maximum of 285.4. Real GDP per capita has a mean of 6.56 and a standard deviation of 1.04 and varies between a minimum of 4.90 and a maximum of 9.26. Military expenditure has an average of 1.79 and a standard deviation of 2.54 and varies between the minimum of 0 and a maximum of 21.98. Lastly, ethnic fractionalization has a mean of 0.82 and a standard deviation of 0.09 and varies between a minimum of 0.64 and a maximum of 0.95 . 
Descriptive statistics

\begin{tabular}{|l|l|l|l|l|}
\hline Variable & Mean & $\begin{array}{l}\text { Standard } \\
\text { deviation }\end{array}$ & Maximum & Minimum \\
\hline Iconflict & 7.26 & 2.38 & 10.93 & 1.36 \\
\hline Oil & 13.45 & 18.9 & 66.23 & 0.00 \\
\hline Polity & 3.82 & 2.43 & 9.33 & 0.75 \\
\hline OilPolity & 41.36 & 66.06 & 285.4 & 0.00 \\
\hline Rgdpc & 6.56 & 1.04 & 9.26 & 4.90 \\
\hline Mexp & 1.79 & 2.54 & 21.98 & 0.00 \\
\hline Ethnfr & 0.82 & 0.09 & 0.95 & 0.64 \\
\hline
\end{tabular}

Source: Eviews 9.5 output using data from WDI, QOGI and ICRG.

Note that all the variables have 140 observations and only the Real GDP Per Capita is in its log form.

The model examines the effects of oil, democracy and their interactions on internal conflict in Sub-Saharan Africa. Following the estimation using panel regression, the estimation suggests a random effect model as the Hausman test fails to reject the null hypothesis at even a $10 \%$ significance level (Table 3).

\section{Random effect model result}

\begin{tabular}{|c|c|c|c|}
\hline & & st Hypothes & \\
\hline & Cross-section & Time & Both \\
\hline Breusch-Pagan & $\begin{array}{l}20.12124 \\
(0.0000)\end{array}$ & $\begin{array}{l}5.844982 \\
(0.0156)\end{array}$ & $\begin{array}{l}25.96623 \\
(0.0000)\end{array}$ \\
\hline Honda & $\begin{array}{l}4.485671 \\
(0.0000)\end{array}$ & $\begin{array}{l}2.417640 \\
(0.0078)\end{array}$ & $\begin{array}{l}4.881378 \\
(0.0000)\end{array}$ \\
\hline King-Wu & $\begin{array}{l}4.485671 \\
(0.0000)\end{array}$ & $\begin{array}{l}2.417640 \\
(0.0078)\end{array}$ & $\begin{array}{l}4.727499 \\
(0.0000)\end{array}$ \\
\hline Standardized Honda & $\begin{array}{l}6.390124 \\
(0.0000)\end{array}$ & $\begin{array}{l}2.857446 \\
(0.0021)\end{array}$ & $\begin{array}{l}2.346903 \\
(0.0095)\end{array}$ \\
\hline Standardized King-Wu & $\begin{array}{l}6.390124 \\
(0.0000)\end{array}$ & $\begin{array}{l}2.857446 \\
(0.0021)\end{array}$ & $\begin{array}{l}2.150780 \\
(0.0157)\end{array}$ \\
\hline Gourieroux, et al.* & - & - & $\begin{array}{l}25.96623 \\
(0.0000)\end{array}$ \\
\hline
\end{tabular}


The random effect model result that incorporate countries fixed effects and time effects are presented in table 4 below.

Table 4

Oil, Democracy and Internal conflict in Sub-Saharan Africa (1983-2012)

\begin{tabular}{|c|c|c|c|c|}
\hline Variable & $\begin{array}{l}\text { Internal } \\
\text { conflicts }\end{array}$ & (1) REM & (2) REM & (3) REM \\
\hline Oil & $\begin{array}{l}0.053 * * * \\
0.032 \\
0.059 * *\end{array}$ & $(0.019)$ & $(0.021)$ & $(0.019)$ \\
\hline Polity & $\begin{array}{l}0.455^{* * *} * \\
0.208 * * \\
0.546 * * *\end{array}$ & $(0.096)$ & $(0.098)$ & $(0.097)$ \\
\hline Oil*Polity & $\begin{array}{l}-0.009 * \\
-0.009 * * \\
-0.009 * *\end{array}$ & $(0.004)$ & $(0.004)$ & $(0.004)$ \\
\hline Lnrgdpc & $\begin{array}{l}0.549 * * \\
0.593 * * \\
0.462 *\end{array}$ & $(0.272)$ & $(0.258)$ & $(0.279)$ \\
\hline Mexp & $\begin{array}{l}-0.204 * * * \\
-0.207 * * * \\
-0.210^{* * *}\end{array}$ & $(0.077)$ & $(0.054)$ & $(0.085)$ \\
\hline Ethnfr & $\begin{array}{l}2.476 \\
2.236 \\
2.691 \\
\end{array}$ & $(3.717)$ & (4.197) & (3.196) \\
\hline $\begin{array}{l}\text { Country Fixed } \\
\text { Effects }\end{array}$ & & Yes & Yes & Yes \\
\hline Time Effects & & Yes & Yes & No \\
\hline $\begin{array}{l}\text { Breusch-Pagan } \\
\text { test: }\end{array}$ & $25.97(0.000)$ & & & \\
\hline Hausman test: & $5(0.44)$ & & & \\
\hline R-squared & & 0.28 & 0.52 & 0.36 \\
\hline F statistics/Prob. & & $8.73(0.0000)$ & $8.94(0.0000)$ & $12.61(0.0000)$ \\
\hline Observations & & 140 & 140 & 140 \\
\hline Countries & & 14 & 14 & 14 \\
\hline
\end{tabular}

Note: The dependent variable is an internal conflict. An increase in internal conflict means less internal conflict. The robust standard errors are reported in brackets. $* * * * * *$ represent $1 \%, 5 \%$ and $10 \%$ significance level. Marginal effects of oil on the conflict in column one at minimum polity, average polity, and maximum polity are $0.04625,0.01862$ and -0.03097 respectively.

The estimation result for model two depicted in table 4 shows no satisfactory evidence that oil increases the risk of internal conflict in Sub-Saharan Africa. The results from column one testify that oil reduces the risk of internal conflict in SSA at a $1 \%$ significance level. Specifically, it shows that, when time effect is considered, an increase in oil by $1 \%$ standard deviation would decrease the risk of internal conflict by $42 \%$ standard deviation.

The result is obtained by initially multiplying the coefficient of the absolute value of the independent variable (oil), 0.053 by its standard deviation, 18.9 (Re- 
fer to table 4) and divide the product by the standard deviation of the dependent variable (Iconflict), 2.38 (Also in table 4). (i.e., $0.053 * 18.9 / 2.38=0.42$ ) (table 5).

Table 5

\section{Model Pooled OLS result}

\begin{tabular}{|c|c|c|c|c|}
\hline \multicolumn{5}{|c|}{$\begin{array}{l}\text { Dependent Variable: ICONFLICT } \\
\text { Method: Panel Least Squares } \\
\text { Date: } 04 / 08 / 17 \text { Time: } 06: 12 \\
\text { Sample: } 20052014 \\
\text { Periods included: } 10 \\
\text { Cross-sections included: } 14 \\
\text { Total panel (balanced) observations: } 140\end{array}$} \\
\hline Variable & Coefficient & Std. Error & t-Statistic & Prob. \\
\hline C & 1.525607 & 1.728755 & 0.882489 & 0.3791 \\
\hline OIL & 0.042123 & 0.021782 & 1.933847 & 0.0553 \\
\hline POLITY & 0.476814 & 0.080270 & 5.940150 & 0.0000 \\
\hline OILPOLITY & -0.005110 & 0.005798 & -0.881231 & 0.3798 \\
\hline LNRGDPC & 0.310835 & 0.180695 & 1.720219 & 0.0877 \\
\hline MEXP & -0.303041 & 0.064748 & -4.680341 & 0.0000 \\
\hline ETHNFR & 2.533294 & 1.870380 & 1.354428 & 0.1779 \\
\hline R-squared & 0.418948 & \multicolumn{2}{|c|}{ Mean dependent var } & 7.263194 \\
\hline Adjusted R-squared & 0.392735 & \multicolumn{2}{|c|}{ S.D. dependent var } & 2.384071 \\
\hline S.E. of regression & 1.857841 & \multicolumn{2}{|c|}{ Akaike info criterion } & 4.125413 \\
\hline Sum squared resid & 459.0590 & \multicolumn{2}{|c|}{ Schwarz criterion } & 4.272496 \\
\hline Log likelihood & -281.7789 & \multirow{2}{*}{\multicolumn{2}{|c|}{ Hannan-Quinn criter. }} & 4.185183 \\
\hline F-statistic & 15.98251 & & & 0.660147 \\
\hline Prob(F-statistic) & 0.000000 & \multicolumn{2}{|c|}{ Durbin-Watson stat } & \\
\hline
\end{tabular}

The result is structurally indifferent when time effect is ignored in column three because it shows that a $1 \%$ standard deviation increase in oil decreases the likelihood of internal conflict in SSA by $47 \%$ standard deviation at a $1 \%$ level of significance. However, these results have contradicted the resource curse theory and some shreds of evidence $[20 ; 24 ; 28]$.

The possible explanation for the recent development may not be unconnected with the fact that oil in itself is a blessing as reiterated by Brunnschweiler and Bulte [37] that resource rents (oil inclusive) are a blessing for countries growth and development. Therefore, oil might be a curse as a result of other factors such as weak institutions and the absence of fair distribution mechanisms that channel oil rent to improve the wellbeing of the people [24]. It is noteworthy that most of the developed countries endowed with oil and gas such as Norway, Canada, and Russia do not face internal conflict because of the strong institution and government commitment as noted by Wizarat [25] that oil and gas do not breed conflict in developed countries. In the context of Sub-Saharan Africa, this study coincides with Arezki and Gylfason [31]. Also, these findings are in tandem with the results from Basedau and Lay [29] and Bruckner and Gradstein [32].

To further strengthen our result on oil and internal conflict nexus, results in table 6 . 


\section{Lagrange multiplier test result}

Lagrange Multiplier Tests for Random Effects

Null hypotheses: No effects

Alternative hypotheses: Two-sided (Breusch-Pagan) and one-sided (all others) alternatives

\begin{tabular}{|c|c|c|c|}
\hline & \multicolumn{3}{|c|}{ Test Hypothes is } \\
\hline & Cross-section & Time & Both \\
\hline Breusch-Pagan & $\begin{array}{l}20.12124 \\
(0.0000)\end{array}$ & $\begin{array}{l}5.844982 \\
(0.0156)\end{array}$ & $\begin{array}{l}25.96623 \\
(0.0000)\end{array}$ \\
\hline Honda & $\begin{array}{l}4.485671 \\
(0.0000)\end{array}$ & $\begin{array}{l}2.417640 \\
(0.0078)\end{array}$ & $\begin{array}{l}4.881378 \\
(0.0000)\end{array}$ \\
\hline King-Wu & $\begin{array}{l}4.485671 \\
(0.0000)\end{array}$ & $\begin{array}{l}2.417640 \\
(0.0078)\end{array}$ & $\begin{array}{l}4.727499 \\
(0.0000)\end{array}$ \\
\hline Standardized Honda & $\begin{array}{l}6.390124 \\
(0.0000)\end{array}$ & $\begin{array}{l}2.857446 \\
(0.0021)\end{array}$ & $\begin{array}{l}2.346903 \\
(0.0095)\end{array}$ \\
\hline Standardized King-Wu & $\begin{array}{l}6.390124 \\
(0.0000)\end{array}$ & $\begin{array}{l}2.857446 \\
(0.0021)\end{array}$ & $\begin{array}{l}2.150780 \\
(0.0157)\end{array}$ \\
\hline Gourieroux, et al.* & -- & -- & $\begin{array}{l}25.96623 \\
(0.0000)\end{array}$ \\
\hline
\end{tabular}

Lagrange indicated that democracy proxy by polity reduces the risk of internal conflict in SSA. The results from columns one, two and three vindicated that $1 \%$ standard deviation increase in polity significantly leads to a reduction in the likelihood of internal conflict by $46 \%, 21 \%$, and $56 \%$ standard deviations respectively. This result implied that democracy (polity) alone tends to increase the likelihood of peace in SSA because democracy would ensure the possibility of having a government that is committed to its people. However, empirical evidence by Collier and Hoeffler [10] contradicts this, still studies by Bodea and Elbadawi, [43] and Elbadawi and Soto [28] have lent support for this finding by noting that political institution reduces the likelihood of civil conflict onset. The finding from this study is in line with the proposition of the international community that, democracy is the best strategy for promoting peace because accountability as a guiding principle of democracy helps in reducing the likelihood of conflict. The marginal effects of the interaction between oil and polity implied that an increase in oil rent reduces the likelihood of internal conflict in SSA at a minimum and an average level of polity only. In column one, the total effect of oil rent on internal conflict is calculated as dIconflict/dOil $=0.053-0.009 *$ Polity $^{2}$. This interaction

${ }^{2}$ To obtain the maximum marginal effect, the absolute value of the coefficient of the interaction term is multiplied by the maximum value of polity in the sample. Thus, in our sample, South Africa has the highest polity score of 9.3. (i.e., $0.053-0.009 * 9.3=-0.03097$ ). Also, the 
term is found to be statistically significant such that a $1 \%$ overall increase in oil leads to a $4.63 \%$ reduction in internal conflict for SSA countries with the minimum polity score. However, the average value of the marginal effect of the interaction term reduces internal conflict by $1.86 \%$ in the sample. On the other hand, such interaction leads to an increase of $3.09 \%$ in the internal conflict in SSA countries with a maximum polity score (table 7).

Table 7

\section{Robust random effect model result with fixed time effect}

\begin{tabular}{|c|c|c|c|c|}
\hline $\begin{array}{l}\text { Dependent Variabl } \\
\text { Method: Panel EGL } \\
\text { Date: 04/08/17 Tin } \\
\text { Sample: } 2005201 \\
\text { Periods included: } 1 \\
\text { Cross-sections inc } \\
\text { Total panel (balano } \\
\text { Swamy and Arora } \\
\text { White cross-sectio } \\
\text { WARNING: estimat }\end{array}$ & $\begin{array}{l}\text { Ss-section r } \\
16 \\
\text { servations: } \\
\text { tor of compo } \\
\text { dard errors } 8 \\
\text { efficient cova }\end{array}$ & $\begin{array}{l}0 \\
\text { nt variances } \\
\text { ovariance (d } \\
\text { nce matrix is }\end{array}$ & $\begin{array}{l}\text { corrected) } \\
\text { of reduced }\end{array}$ & \\
\hline Variable & Coefficient & Std. Error & t-Statistic & Prob. \\
\hline C & 1.100105 & 4.230059 & 0.260068 & 0.7952 \\
\hline OIL & 0.031751 & 0.021111 & 1.504017 & 0.1351 \\
\hline POLITY & 0.207565 & 0.098215 & 2.113368 & 0.0366 \\
\hline OILPOLITY & -0.009697 & 0.004722 & -2.053360 & 0.0421 \\
\hline LNRGDPC & 0.592990 & 0.258329 & 2.295486 & 0.0234 \\
\hline MEXP & -0.206650 & 0.053892 & -3.834517 & 0.0002 \\
\hline ETHNFR & 2.236187 & 4.197115 & 0.532791 & 0.5951 \\
\hline
\end{tabular}

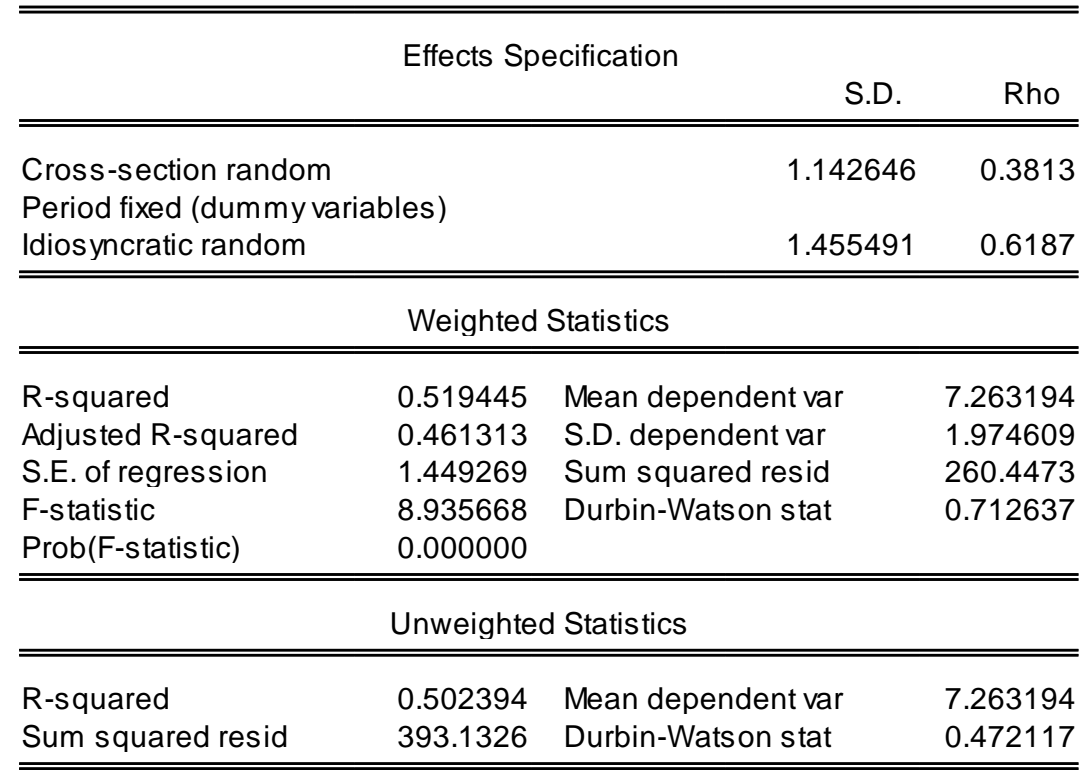

minimum marginal effect is obtained by multiplying the interaction coefficient by the minimum value of polity in the sample. (i.e., $0.053-0.009 * 0.75=0.04625$ ). The same process applies to the marginal average effect of polity on conflict. 
The marginal effect of the interaction term has the same effects when we controlled for fixed time effect in column two as well as when time effects are ignored in column three. This result coincides with findings from Arezki and Gylfason [31] that, natural resources countries with less democracy experienced less internal conflict. This finding seems to be surprising but the study by Fedderke and Klitgaard [42] found a similar effect in developing countries and described the outcome as transitional uncertainty from autocracy to improved democracy. The result from table 2 shows that an increase in real GDP per capita increases the likelihood of peace in SSA. This is because results from columns one and two show that a $1 \%$ standard deviation increase in real GDP per capita reduces the risk of internal conflict by $23.9 \%$ and $25.9 \%$ standard deviation both at a $5 \%$ significance level after taking time effects into cognizant. In the same vein, the result seems to be similar when the time effect is ignored in column three (table 8).

Table 8

\section{Robust random effect model result with random time effect}

\begin{tabular}{|c|c|c|c|c|}
\hline $\begin{array}{l}\text { Dependent Variable: I } \\
\text { Method: Panel EGLS } \\
\text { Date: } 04 / 08 / 17 \text { Time } \\
\text { Sample: } 20052014 \\
\text { Periods included: } 10 \\
\text { Cross-sections incluc } \\
\text { Total panel (balanced } \\
\text { Swamy and Arora esti } \\
\text { White cross-section s }\end{array}$ & $\begin{array}{l}14 \\
\text { servations: } 1 \\
\text { or of compor } \\
\text { lard errors \& }\end{array}$ & ndom effects) & corrected) & \\
\hline Variable & Coefficient & Std. Error & t-Statistic & Prob. \\
\hline $\mathrm{C}$ & -0.086927 & 3.633182 & -0.023926 & 0.9809 \\
\hline OIL & 0.059446 & 0.018941 & 3.138415 & 0.0021 \\
\hline POLITY & 0.545524 & 0.096837 & 5.633426 & 0.0000 \\
\hline OILPOLITY & -0.009275 & 0.004363 & -2.125736 & 0.0354 \\
\hline LNRGDPC & 0.462320 & 0.278694 & 1.658879 & 0.0995 \\
\hline MEXP & -0.210147 & 0.085482 & -2.458367 & 0.0152 \\
\hline \multirow[t]{3}{*}{ ETHNFR } & 2.691198 & 3.195984 & 0.842056 & 0.4013 \\
\hline & \multirow{2}{*}{\multicolumn{2}{|c|}{ Effects Specification }} & & \\
\hline & & & S.D. & Rho \\
\hline \multirow{2}{*}{\multicolumn{3}{|c|}{ Cross-section random }} & 1.119147 & 0.3209 \\
\hline & & & 1.627870 & 0.6791 \\
\hline \multicolumn{5}{|c|}{ Weighted Statistics } \\
\hline R-squared & 0.362568 & \multirow{5}{*}{\multicolumn{2}{|c|}{$\begin{array}{l}\text { Mean dependent var } \\
\text { S.D. dependent var } \\
\text { Sum squared resid } \\
\text { Durbin-Watson stat }\end{array}$}} & 3.035184 \\
\hline Adjusted R-squared & 0.333812 & & & 1.992920 \\
\hline S.E. of regression & 1.626629 & & & 351.9074 \\
\hline F-statistic & 12.60830 & & & 0.812333 \\
\hline Prob(F-statistic) & 0.000000 & & & \\
\hline \multicolumn{5}{|c|}{ Unweighted Statistics } \\
\hline R-squared & 0.395307 & \multirow{2}{*}{\multicolumn{2}{|c|}{$\begin{array}{l}\text { Mean dependent var } \\
\text { Durbin-Watson stat }\end{array}$}} & 7.263194 \\
\hline Sum squared resid & 477.7366 & & & 0.598376 \\
\hline
\end{tabular}


It shows that a $1 \%$ standard deviation increase in real GDP per capita reduces the likelihood of internal conflict by $20.2 \%$ standard deviation at a $10 \%$ significant level. These findings are in tandem with the result of Elbadawi and Soto [28]. However, an increase in military expenditure does not reduce the risk of internal conflict in SSA. Specifically, the results show that a $1 \%$ standard deviation increase in military expenditure significantly increases the likelihood of internal conflict by $21.8 \%, 22.1 \%$ and $22.4 \%$ standard deviations in columns one, two, and three respectively. Interestingly, this result is in line with the reality of situations in some SSA countries. For instance, military operations over the years in the oil-rich Niger Delta region and Boko Haram in Northeastern, Nigeria do not eliminate the spade of conflict in the region rather such operations tend to exacerbate the crisis by germinating more rebel groups. Another case in point, the military intervention in Sudan and South Sudan has always deteriorated and fueled the crisis and that is why even after the secession of South Sudan as a sovereign state peace has being a mirage.

Although, the proponents of the rentier theory viewed that internal conflict in oil-rich countries can be ameliorated through repression (military intervention), co-optation and bribery but this finding does not seem to support the positive effect of military intervention rather it coincides with the findings from Singh, et al. [11] revealing the ineffectiveness of military spending in reducing the risk of internal conflict. You can found that high military spending crowds out social spending, economic growth, and investment, subsequently erupting grievances and increases the likelihood of insurgency. Teydas and Peksen [30] found that military spending has no impact on the onset of civil war. The result in table 2 shows that ethnic fractionalization does not affect internal conflict in SSA. Even though, studies by Collier and Hoeffler [20] identifies ethnic fractionalization as a culprit for internal conflict but Besadau and Lay [29] found similar findings that ethnic fractionalization is immaterial in influencing internal conflict.

\section{Conclusion and Policy Recommendation}

Having explored the nexus between oil, democracy and internal conflict in Sub-Saharan Africa (SSA) during the period from 1983-2012, this study unraveled that oil rents do not breed internal conflict in SSA. Oil rents instead increase the likelihood of achieving and maintaining peace and stability if judiciously utilize in uplifting the wellbeing of the people. The study also concludes that democracy proxy by polity is a significant factor in increasing the likelihood of achieving peace in SSA countries endowed with oil resources. More importantly, the mitigating effects of oil on conflict is amplified downward only at the lower and average levels of polity. However, at the maximum level of polity in SSA, the marginal effect of polity is unfavorable. This is quite surprising, but the implication of this finding is reported by Fedderke and Klitgaard [44] that, the negative outcome at the maximum level of polity in developing countries is connected to political uncertainty due to transition from autocracy to democracy ${ }^{3}$. This paper provides the following recommendations:

\footnotetext{
${ }^{3}$ The maximum polity level in SSA is like a moderate level of polity at the global level.
} 
1. Since the empirical findings of this study provide a U-turn from the resource curse theory in the sample of SSA used, SSA should note that oil is a blessing for them and should ensure its optimum utilization to reduce internal conflict. This is because the current mitigating impact of oil on internal conflict is discouraging as shown in the results in table two.

2. We acknowledged the fact that improvement in political institutions (democracy) accrue benefits to SSA in terms of increasing the likelihood of peace hence, it should be pursued vigorously. However, the manifestation of conflict at the maximum level of the polity should not deter SSA in the pursuance of an improved political system. This is because the transitional cost from autocracy to democracy will greatly diminish as they continue in the pursuance of higher and improved political institutions. The achievement of peace and stability in SSA countries would have positive multiplier effects on the African continent in specific and the world at large.

3. It is of utmost importance that governments in SSA countries should restrategize their security architecture by reducing their expenditure on military and other security apparatus for tackling internal conflict since such spending is considered futile and even tend to fuel the crisis. Therefore, this study identifies the significance of improvement in real GDP per capita which the oil rents have the potential as a viable alternative to achieving sustained peace, growth, and development.

4. The governments in SSA countries should not be distracted by the fractionalized nature of their societies and concentrate on the core issues that improve the livelihood of their people.

5. The government in SSA countries should ensure that oil exploration does not cause huge environmental damages and effort should be put in place to ensure frequent abatement of oil spillage due to exploration activities. This should complement by providing improved social services such as clean drinking water, education, health care delivery, etc. These will mitigate the grievances from the oil communities thereby reducing internal conflict.

\section{REFERENCES}

[1] Oyefusi A. Oil-dependency and Civil Conflict in Nigeria. Department of economics and statistics, University of Benin, Nigeria. CSAE WPS 2007-09. 2007.

[2] Fearon J., Laitin D. Ethnicity, Insurgency, and Civil War. American Political Science Review. 2003; Vol 97-1: 75-90.

[3] Human Security Report Project. Human Security Report: Sexual Violence, Education, and War - Beyond the Mainstream Narrative. Human Security Press; 2012.

[4] Albuja S. Internally Displacement Monitoring Centre (IDMC) and Norwegian Refugee Council. Global Overview 2012. People Internally Displaced by Conflicts and Violence; 2013.

[5] Osman R.H., Alexion C., Tsaliki P. The Role of Institutions in Economic Development: Evidence from 27 Sub-Saharan African Countries. International Journal of Social Sciences. 2011; 39 (1/2): 142-160.

[6] Aghalino S.O. Gas Flaring, Environmental Pollution, and Abatement Measures in Nigeria, 1969-2001. Journal of Sustainable Development in Africa. 2009; 11 (4).

[7] World Bank. World Development Indicators. Washington, D.C.: World Bank; 2016. 
[8] Auty R.M. Sustaining Development in Mineral Economies: The Resource Curse Thesis. Routledge, London, and New York; 1993.

[9] Sachs J.D., Warner A.M. Natural Resources Abundance and Economic Growth. National Bureau of Economic Research. Working Paper no. 5398; 1995.

[10] Collier P., Hoeffler A. High-value Natural Resources, Development and Conflict. Channels of Causation. High-Value Natural Resources and Peacebuilding. London: EarthCam; 2012.

[11] Singh R.J., Bodea C., Higashijima M. Oil and Civil Conflict: Can Public Spending Have a Mitigating Effect? Policy Research Working Paper, 7100. 2014.

[12] Ramey G., Ramey V.A. Cross-Country Evidence on the Link between Volatility and Growth. American Economic Review. 1995; 85: 113.

[13] Fearon J.D. Primary Commodity Exports and Civil War. Journal of Conflict Resolution. 2005; 49 (4): 483-507.

[14] Humphreys M. Natural Resources Conflict and Conflict Resolution: Uncovering the Mechanism. Journal of Conflict Resolution. 2005; 49: 508-537.

[15] Belbo R. Petroleum Resources and Internal Conflict. Master's Thesis in Peace and Conflict Studies. Department of Political Science Faculty of Social Science, University of Oslo. 2014.

[16] Collier P., Hoeffler A., Rohner D. Beyond Greed and Grievance. Feasibility and Civil War. Oxford Economic Papers. 2009; 61: 1-27.

[17] Cotet A.M., Tsui K.K. Oil and Conflict: What Does the Cross Country Evidence Really Show? Ball State University and Clemson University; 2010.

[18] Fish M.S. Democracy Derailed in Russia. NY: Cambridge University Press; 2005.

[19] Ross M.L. Oil and Democracy Revisited. Los Angeles: UCLA Department of Political Science; 2009.

[20] Collier P., Hoeffler A. Greed and Grievances in a Civil War. Oxford Economic Papers. 2004; 56: 563-595.

[21] Lujala P. The Spoils of Nature. Armed Conflict and Rebel Access to Natural Resources. Journal of Peace Research. 2010; 47 (1): 15-28.

[22] Fleming D.A., Mesagan T.H. Disentangling the Natural Resource Curse: National and Regional Socio-economic Impact of Resource Windfalls. Social and Economic Science Research Program. Black Mountain Laboratories. ACT 2601; Australia; 2013.

[23] Roy B.C, Sarkar S., Mandal N.R. Natural Resources Abundance and Economic Performance. A Literature Review. Current Urban Studies. 2013; 1 (4): 148-155.

[24] Le Billion P. Diamond Wars? Conflict Diamond and Geographies of Resources Wars. Annals of the Association of American Geographers. 2008; 98 (2): 345-372.

[25] Wizarat S. Natural Resources, Conflict and Growth Nexus. Asian Economic and Financial Review. 2013; 3 (8): 1063-1082.

[26] Berman N., Couttenier M., Rohner D., Thoenig M. This Mine is Mine! How Minerals Fuel Conflicts in Africa. Centre for Economic Policy Research (CEPR) discussion paper No. 10089. 2014

[27] Anyanwu J.C. Oil Wealth, Ethnoreligious-linguistic Fractionalization and Civil Wars in Africa: Cross Country Evidence. African Development Review. 2014; 26 (2): 209-236.

[28] Elbadawi I.A., Soto R. Resource Rents, Institutions, and Violent Civil Conflicts. Defense and Peace Economics. 2015; 26 (1): 89-113.

[29] Basedau M., Lay J. Resource Curse or Rentier Peace? The Ambiguous Effect of Oil Wealth and Oil Dependence on Violent Conflict. A Journal of Peace Research. 2009; 46 (6): 757-776.

[30] Teydas Z., Peksen D. Can the State Buy Peace? Social welfare spending and civil conflicts. Journal of Peace Research. 2012; Vol. 49 (2): 273-287.

[31] Arezki R., Gylfason T. Resource Rents, Democracy, Corruption, and Conflict: Evidence from Sub-Saharan Africa. Journal of African Economie. 2013; Vol. 0, No. 0: 1-18. 
[32] Bruckner, M. and Gradstein, M.,Income growth, ethnic polarization, and political risk: Evidence 2014from International Oil price shocks. Journal of Comparative Economic Development. 43: 575-594.

[33] Ahmadov, I., Mammadov, J., and Aslanli, K. Assessment of institutional quality in resource-rich Caspian Basin Countries. Department of economic and management, Khazar University, Azerbaijan. 2013.

[34] Anyanwu, J C. and Erhijakpor, E. O. (). Does Oil Wealth Affect Democracy in Africa? African Development Review. 2014; Vol. 26, No. 1.

[35] Dunning, T. (2008). Crude Democracy. Natural Resource Wealth and Political Regimes. New York. Cambridge University Press.

[36] Ebeke, C., Omgba, L. D. and Laajaji, R. (). Oil, governance and the misallocation of talent in developing countries. Journal of Development Economics. 2015; 114: 126-141.

[37] Brunnshcweiler C.N., Bulte E.H. The Resource Curse: Revisited and Revised. A Tale of Paradoxes and Red Herrings. Centre of Economic Research at ETH Zurich. Working Paper no. 06/61. 2006.

[38] Alao A., Olanisakin F. Economic Fragility and Economic Fluidity: Explaining Natural Resources and Conflicts. International Peacekeeping. 2000; 7 (4): 23-36.

[39] Collier P., Rohner D. Democracy, Development, and Conflict. Journal of the European Economic Association. 2008; 6 (2-3): 531-540.

[40] Kevin M.M. Oil, Conflict, and Stability. A Paper Presented at the New York University, Wilf Family Department; U.S. 2010.

[41] Ross M. L. The Oil Curse. New Jersey: Princeton University Press; 2012.

[42] UCDP/PRIO. Armed Conflict Dataset (2016). Available from: http://www.prio.no/ CSCW/Datasets/Armed-conflict/UCDP-PRIO/. Accessed: 05.10.2019.

[43] Bodea C., Elbadawi A.I. Riots, Coups, and Civil War: Revisiting the Greed and Grievance Debate. Policy Research Working Paper. 2007; WPS4397.

[44] Fedderke J., Klitgaard R. How Much Do the Right Matter? World Development. 2013; 51: 187-206.

Научная статья

\title{
Нефть, демократия и внутренний конфликт в странах Субсахарской Африки
}

\author{
А. Коле \\ Политехнический институт Май Идрис Алума \\ ул. Гейдам, 49, штат Йобе, Нигерия
}

\begin{abstract}
Аннотация. В данном исследовании рассматривается влияние нефти и демократии на внутренние конфликты в странах Субсахарской Африки (ССА). В исследовании использовалась регрессивная модель панельных данных по 14 богатым нефтью Субсахарским странам, охватывающая период с 1983 по 2012 годы. Основной вывод указывает на тенденции, которые не соответствуют положениям часто применяемой в подобных случаях теории ресурсного проклятия и ясно показывает, что увеличение добычи нефти ведет к снижению вероятности возникновения внутренних конфликтных ситуаций в ССА. В исследование присутствуют убедительные доказательства значимости политических институтов в смягчении внутреннего конфликта в ССА. Тем не менее, взаимосвязь между нефтью и демократией снижает риск возникновения внутренних конфликтов в странах ССА с наименьшим и средним политическим баллом и
\end{abstract}


увеличивает конфликт в ССА с максимальным политическим баллом. Этот результат обычно ожидается в процессе перехода от самодержавия к демократии в развивающихся странах. Поэтому с дальнейшим улучшением политических институтов смягчающее воздействие нефти на внутренний конфликт вновь проявится. Подразумевается, что нефть сама по себе является благом и ведет к достижению мира, когда страны совершенствуют свои политические институты. Кроме того, исследование показало, что, хотя рост реального ВВП снижает шансы на внутренние конфликты в ССА, увеличение военных расходов имеет тенденцию также понижать вероятность мира, что вступает в некоторое противоречие с положениями концепции мира-рантье. Таким образом, предполагается, что для поддержания мира в ССА следует сократить расходы на вооруженные силы и увеличить расходы на социальные нужды, одновременно улучшая политические системы стран.

Ключевые слова: нефть, демократия, внутренний конфликт, регрессивная модель панельных данных, Субсахарская Африка

\section{Информация об авторе:}

Коле Али - заведующий кафедрой маркетинга Политехнического института Май Идрис Алума (Нигерия) (ORCID ID: 0000-0003-3033-8144) (e-mail: kolegursulu@ gmail.com).

\section{Information about the author:}

Kole Ali - Head of the Department of Marketing, Mai Idris Alooma Polytechnic (Nigeria) (ORCID ID: 0000-0003-3033-8144) (e-mail: kolegursulu@gmail.com).

\section{Для цитирования:}

Kole A. Oil, Democracy and Internal Conflict in Sub-Saharan Africa // Вестник Российского университета дружбы народов. Серия: Государственное и муниципальное управление. 2019. Т. 6. № 4. С. 268-285. DOI: DOI: 10.22363/2312-8313-2019-6-4-268-285

\section{For citation:}

Kole A. Oil, Democracy and Internal Conflict in Sub-Saharan Africa. RUDN Journal of Public Administration. 2019; 6 (4): 268-285. DOI: DOI: 10.22363/2312-8313-2019-6-4268-285 